\title{
Inspiration from Green Effect of South Korea's Low-Carbon Economy Development to China
}

\author{
Dong-Xin $\mathrm{Li}^{1}$, Taewon Kang ${ }^{2}$ \\ ${ }^{1}$ School of International Relations and Public Affairs, Fudan University, Shanghai, China; ${ }^{2}$ School of Management, Zhejiang Ocean \\ University, Zhoushan, China. \\ Email: lidongxin@fudan.edu.cn, jiangtaiyuan@gmail.com
}

Received October $20^{\text {th }}, 2012$; revised November $7^{\text {th }}$, 2012; accepted November $24^{\text {th }}, 2012$

\begin{abstract}
Low-carbon economics is a new model of economic development in both international and domestic settings as well as the only way for all mankind to deal with climate change and achieve sustainable economic development. In addition to controlling carbon dioxide emissions, the low-carbon economic development model indicates an energy revolution that will fundamentally change production as well as people's social and economic lifestyle. Low-carbon development has drawn close attention from the international community and has progressed into action in many countries. The world is gradually approaching the low-carbon age for the main purpose of pursing low energy consumption, low emission and high efficiency. The low-carbon economic cooperation aimed at environmental diplomacy is also in the process of active and effective negotiation and implementation. This paper will introduce the low-carbon economic development strategies in South Korea and the results in practice so far and then summarize the applicable experience and inspiration from the practical significance of South Korea to China.
\end{abstract}

Keywords: Low-Carbon Economy; Energy Revolution; International Cooperation; Economic Policy

\section{Introduction}

With the emergence of the terms low-carbon economy, green economy and circular economy and ecological economy, various countries in the world began to adhere to the spirit of the Conference in Bali and the purpose of Kyoto Protocol in the context of dealing with climate changes to pursue sustainable economic development. China and South Korea are also facing these challenges and opportunities, so the governments have continually introduced policies to promote the realization of a lowcarbon economy and hope to achieve a true eco-economy in the future. With the increasing competition of lowcarbon and low carbon technology barriers, all countries think about their suitable low-carbon technologies and strategies. Therefore, low-carbon transformation has become the epochal thought and the inevitable trend. The society is also expanding the role of low-carbon in the corporate social responsibilities, producing new understanding of the corporate social responsibility, reshaping the image of enterprise, society and citizen through lower carbon emissions, and promoting sustainable development in the national economy.

The economic cooperation between China and South Korea has been focusing on the study and cooperation of sustainable economic development models with the con- cept of green growth at its core in both countries in recent years. However, important prerequisite's for these discussions are the necessity, feasibility and relatively bright future of sustainable economic development and cooperation. Moreover, in recent years, both national governments have offered strong policy support. All countries expect to find out the best ecological model of economic development through their energy strategy. With the rise of China, which is an important partner in the international trade, South Korea's economic dependence on China is becoming more and more visible.

Generally, the economic fit and interdependence between China and South Korea is extensive. Due to the failure of obtaining corresponding theoretical guidance, most are distributed evenly in various refined areas. If political obstacles cannot be effectively resolved, the economic cooperation in East Asia is bound to be faced with a situation of power shortage and/or organizational laxity. However, this study will first start from the low-carbon economic development strategies in Korea in order to lay a foundation for future low-carbon economic cooperation between China and Korea. In other words, during the process in which low-carbon economic development and cooperation between China and South Korea grows from a low stage (economic integration) to the advanced stage (political and social integration), it is 
necessary to study and analyze South Korea's low-carbon economic development strategies and then elevate them to an economic and trade development theory of strong operability and instructional meaning. This can assist the theories of China's sustainable economic development foster a harmonious international trade relationship and play a guiding role in the successful low-carbon transformation within China.

\section{South Korea Introduces the Low-Carbon Economic Development-From Theory to Action}

South Korea is a country with poor resources and leading population density. Its average per capita amount of arable land is less than an acre. It is in the inherently limited land that Korean economy has created the sustainable and rapidly developed Han River Miracle since the 1960s. Looking at the contributions to success and comparing them with other developing countries that started almost simultaneously (such as Brazil, Argentina and other countries in South America) it can be found that Korea's success is mainly attributed to its government's appropriate selection of economic growth models and developmental strategies that comply with its national conditions according to the environment at home and abroad.

\subsection{The Support and Cooperation of the Relevant Departments in the Government}

Like China, South Korea builds its economy on the energy consumption during the period of rapid economic development. In the era of global warming, such growth strategies lack sustainability [1]. South Korea had an in-depth understanding of the environment early. In August 2008, South Korean President Lee Myung-bak first proposed the Low-Carbon Green New Deal in response to the international situation and emphasized the determination of attaching great importance to green development technology. Since then, all classes of society began to have a deeper understanding of Green New Deal, gradually expanded it, and ultimately issued the Basic Laws of Green New Deal and other relevant policies and regulations [2]. In order to achieve the Green New Deal, President Lee personally set up a Green New Deal Committee and developed the Basic Law of Low-Carbon Green New Deal, which made South Korea widely recognized as the leading country in the Green New Deal. The Korean environmental organization UNEP passed the Report of South Korean Green New Deal Policy and was awarded as the model of Low-Carbon Green New Deal. The South Korean government launched a new green growth plan in 2009 and announced its low-carbon green growth patterns and policies. Currently, based on the green tech- nology, the green industry in South Korea is rising as a new industry. The Basic Law of Low-Carbon Green Growth Development created and promoted by the Korean Government was formally passed in January 2001, providing the legal basis for the government's green development policy. In addition, the South Korean government has developed a 3G strategy of green innovation, adjustment of green structure and green value chain which are interrelated [3]. Through the launch of the above three strategies and ten basic policies, the Korean government aims to develop South Korea to be the number seven power in green development in the world and rank top five by 2050. In order to implement the above strategies and promote the green development, the Korean government has also developed a Five-Year Plan from 2009 to 2013 which designs in detail the project promotion and the related annual and industry shift [4].

The South Korean government departments have also taken action. The Ministries of Finance, Environment and Knowledge Economy all take relevant measures to support the research, development, application promotion and industrialization of green information technology and work together to improve the national competitiveness of green information technology, thus achieving the green growth. The Ministry of Finance in South Korea will spend a substantial sum of money in supporting the research and development of green technology and funding the SMEs in South Korea for green technology research and development. Meanwhile, the South Korean government will also provide tax preference to enterprises which research and develop green technology. The Ministry of Environment in South Korea proposes to accelerate the development of ten green technologies, including the seven core technologies of water treatment, green cars, measures for climate change, soil and groundwater contamination purification, the use and restoration of biological resources, environmental protection, and efficient resource recovery, and three basic technologies of basic environmental pollution improvement, greenhouse gas alternatives, living consensus-based environmental products. The Ministry of Knowledge Economy in South Korea has announced an increase in the investment in the R\&D of related technologies in new and renewable energies, published the route map for green resources technology research and development strategy by the government as well as 73 large, medium and small South Korean enterprises (some leading IT enterprises like Samsung and LG serve as the base) and determined 15 sun fields which will become increasingly importance toward 2030. Meanwhile, the South Korean Ministry of Knowledge Economy has made the medium-term objective of reducing the standby power consumption for televisions, computers, monitors, printers, multifunction printers, set-top boxes and microwave ovens. If the standby 
power consumption of these products exceeds the state regulations, they must be labeled with the yellow warning sticker. In addition, the KIPO has also developed and published the Promotion Plan of Green Development Intellectual Property Strategy which emphasizes improving the protection level of technical intellectual property, especially the protection of green IT intellectual property based on the results of demonstration projects in four technical fields such as the new generation of semiconductors and monitors [5].

\subsection{The Active Participation of All Citizens and Successful Realization of the Path of Low-Carbon Transformation}

South Korea is now facing dual tasks. One is to maintain the sustained economic development and the other is to protect the environment through green development strategies and projects. The economic growth of South Korea is based on the input-based expanding model. South Korea is the tenth largest energy consumer in the world. 97\% of its energy is imported. Nowadays, due to the crisis of climate change, South Korea is changing the economic development model to achieve the new development model of a low-carbon and green economy and reduced carbon dioxide emissions [6]. In order to achieve this pattered transformation of economic development, South Korea must adopt a fully integrated mode. Therefore, the South Korean government encourages people to change their modes of thinking and way of life and achieve such a goal with an innovated economy.

In 2009, South Korean President Lee Myung-bak, known for environmental protection, proposed the national strategy for green growth and personally supervised the bottom-up Green National Movement, in an attempt to find a new engine of economic recovery. The aim was to breakthrough to a green philosophy based on the characteristics and advantages of the industrial development within the country. South Korea has always enjoyed a worldwide reputation for its advanced information technology. The integration of strong information technology with emerging green concepts is bound to generate and spark new ideas, thus producing varied results. Today, in various media and research institutions, the green vocabulary such as green growth, low-carbon development, Green New Deal, green jobs and green homes are everywhere. No doubt, the green growth promoted through information technology will become the next competitive point for the economic development in South Korea [7].

The report published by the Ministry of Planning and Finance (Economic Policy Direction in the Second Half of 2010) said that the predictor of economic growth rate of South Korea in 2010 was adjusted from 5\% to 5.8\% and was expected to reach $6.1 \%$ for the year overall [8]; the overall economy continued to grow; three hundred and three thousand jobs were created over the year; the employment rate remained at $58.7 \%$ and the unemployment rate at $3.7 \%$, a $0.1 \%$ increase compared with the value in the same period of last year; the consumer price index was $2.9 \%$. Influenced by the surplus of commodity balance and other factors, the annual recurrent expenditure will achieve a surplus of 1.5 billion dollars. Thanks to the improved competitiveness of the main commodities and the continuous growth of the emerging markets, until the end of 2010, exports and imports are expected to reach $\$ 516$ billion and $\$ 485$ billion and for the first time the total trade will exceed \$1 trillion [9]. And, South Korea will improve its rank from top nine to top seven on the global export scale.

\subsection{Enterprises and Research Institutes Take the Lead in Promoting the Low-Carbon Spiritand}

In order to allow enterprises to learn more about environmental policies and response strategies so as to emphasize corporate social responsibility and expand new elements of education for corporate social responsibility as well as systematizing the green growth strategy in the design industry, South Korean design-related management committee regularly holds the green design seminars. These enhance the employees' understanding of green trends to help convey eco-friendly concepts in their designs. POSCO, Samsung SDI and Liu Han-Kimberley all have recognized the new opportunities for business brought about by climate change and have launched enterprise strategies with low carbon, green, environmental protection and other concepts [10]. The three enterprises can be said to be the most representative manufacturing enterprises in environmental protection in South Korea. Each company has their own strategy to deal with the climate change. The characteristics of the strategies can be summarized as follows: the production process innovation strategy, new product development and business restructuring strategy, corporate social responsibility implementation activities, etc. Among them, POSCO and Samsung SDI have had the similar response strategy of creating new core competency-based business opportunities. POSCO further strengthens its existing advanced iron production technology by integrating it together with new renewable energy technologies. Samsung SDI researches and develops a rechargeable battery based on their semiconductor and monitor technology. They believe that this technology can allow them to grasp the development opportunities brought by climate change. These two companies both started from their existing technology competitiveness to carry out progressive or radical climate change response strategies. Liu Han-Kimberley builds green corporate culture, green education 
systems and other green infrastructure within the enterprise and deals with the climate change through longterm social responsibility activities [10]. From the perspective of new product development and technological innovation, Liu Han-Kimberley's coping strategies do not appear to be as positive as the other two companies. However, it has its advantages in environmental management and practice, thus successfully establishing the image of an environmental protection enterprise and having the possibility of improving its sustainable development.

\subsection{Strengthening the Professional Study and International Cooperation in the Sustainable Economic Field}

In order to better promote and implement the national strategy of green growth, South Korea set up the Green Growth Commission directly under the Office of the President (referred to GGC for short). GGC is composed of 47 members, including three sub-committees, namely the green growth and industry, climate change and energy, green living and sustainable development committees [11]. There is also a green office to determine the target of carbon dioxide emission reduction. In addition to three sub-committees and a green office, GGC has a working group composed of sixty experts from government, private sector and telecommunication companies. The Korean government has also established a green technology research and development coordination mechanism as well as a green technology research and experimental base with the National Science and Technology Committee and Green Development Committee as the cores to ensure core technologies achieve commercialization, which include the six technologies: high efficiency solar cells, marine bio-fuels, carbon dioxide capture, recycling technologies, smart grid, new-generation rechargeable batteries and green computer and appliance technologies.

South Korea and Japan established a joint venture company and have reached an agreement recently of expanding the largest solar power plant in Asia [12]. This plant will provide energy for over 7 million and the annual power generating capacity is very large. In this way, many of families will enjoy clean energy while reducing emissions of sulfur dioxide. As a result, the sulfur dioxide emissions will be reduced up to 24,000 tons by next year. South Korea has been selected as the main country of intelligent grid technology, which was selected at the recent G20 meeting. Now South Korea is establishing a smart grid network which will cover 6000 families [13]. The current technology is limited to retain $20 \%$ of energy consumption. The green value chain will bring the value of green thinking to the industrial sector, establish green standards and take full advantage of IT technology in the green chain. Homeplus, a joint venture between South
Korea and the United Kingdom, has the solar roof and its air conditioning system achieves refrigeration by ice produced at night, which can reduce $30 \%$ of $\mathrm{CO}_{2}$ emissions. Green energy mainly means that the product is produced with the renewable energy including solar from the raw materials to the finished product. Many areas will adopt fuel cells to reduce carbon emissions. The end users of automotive and appliances are closely linked. The central government of South Korea strongly supports this policy and many companies also use our chain model for their operations. Some companies have expanded their business to India, Chile and other countries.

Furthermore, South Korea will implement efficient transportation and green transportation, aiming to become a global supply base for traffic and building materials. We can use the existing opportunities for cooperation with the global companies in shipbuilding and car manufacturing to achieve this goal. Green transport has many advantages and there are many very good companies, some of which have an iron, steel and chemical industry manufacturing background as well as the related test centers. South Korea has been committed to IT cooperation with other countries, areas and enterprises for the long term publicizing and promoting of the national advanced IT, and helping IT enterprises expand their international markets [14]. After the proposal of the concept of green growth, South Korea has spared no effort to actively use its IT advantage to strengthen the cooperation of global green field, thus achieving complementary advantages. South Korea and the United States cooperate to develop future green technologies including cooperation in the area of smart grid networks. In June 2009, the South Korean Ministry of Knowledge Economy and the US Ministry of Energy published a Letter of Intent for Cooperation in the Energy Field, intending to achieve the intelligent grid network as well as energy saving and green growth based on the US power technology with the help of South Korea's IT technology advantages [14]. Also, South Korea and Indonesia further enhanced their cooperation in green growth, information and communication and other fields. Both sides suggest promoting bilateral cooperation in green growth through environmentally friendly power plant construction and strengthening the bilateral IT cooperation through the ICT working conference. In addition, in July 2009, the Korean government signed a cooperative agreement with Ericsson to establish a green ecosystem based on mobile broadband and other communication technologies including machine-to-machine communication. Ericsson was ready to invest $\$ 1.5$ billion (about 200 billion won) for the establishment of an institute for research of the fourth generation system in South Korea

\section{Conclusion and Inspiration to China}

By the use of reverse thinking, the South Korean gov- 
ernment regards the current financial crisis as an opportunity to drive the green growth of the enterprise economy while promoting the green growth of the whole country through green industry restructuring, research and development. South Korea is named as the first country to consider a green strategy program to be a national core development strategy by UNEP. Its ongoing green development strategy programs are strongly systematic. South Korea's new government takes the low carbon economy as a new driving force of economic growth and national competitiveness as well as a favorable factor of promoting environmental diplomacy, which undoubtedly offers some inspiration to Chinese diplomacy policy which is currently facing diplomatic troubles around the promotion of industrial structure adjustment and the transformation of economic development within the country.

\subsection{The Government Should Establish the Correct Role and Adopt the Model Which Is Suitable to China's Sustainable Economic Development.}

From the close cooperation and joint promotion of lowcarbon economy of the South Korean governments, the Chinese government should play the dual role of government and enterprise while attaching importance to the low-carbon economy to understand the markets orientation. It should invest in and support enterprises carrying out green growth technologies, establish the citizens' trust on government and enterprise fundamentally, and implement the guide of green consumption in three directions of government, business and citizens simultaneously. Currently, China has some problems in positioning discrepancy, which makes the economic policy support separately the standpoint for a long term solution without the realistic market research and the communication and supervision of local scholars and the public. The result is that a lot of money isn't fully utilized in the development and promotion of the real low-carbon economy. Therefore, from an investment orientation of the government's supporting funds, in order to guide development and carbon trade of capital towards investing in new energies and to improve high-efficiency technologies research and other low-carbon economic industrial development, it is necessary to take advantage of the experience of South Korea and other countries to build the norms and mechanisms needed to measure green growth-style enterprises.

\subsection{Effective Implementation of Government Orientation, Local Governmental Promotion and the Civic Participation}

China also shows the trend of government orientation in the search for a new green economic development model.
Starting from the national strategic perspective, our country focuses on top-level design, and investigates researches and develops information to promote the policy of green economic development with guidance and supervision. However, as China is a vast region, with great differences among the areas in information technology research, application level and the level of economic and social development, the local governments cannot be generalized in promoting the transformation of regional economic development modes by the use of information technology. They should instead increase the application of information technology in energy saving and emission reduction while studying and learning from the experience and lessons of the advanced areas. In promoting green growth they should use information technology selectively and purposefully according to the real local situations. They cannot blindly copy modes and policies but must shoot the arrow at the target. Most of our people have very poor low-carbon consumer awareness, so the state and local governments should make great efforts to guide people to learn and practice the scientific developing concept, publicize and popularize knowledge of climate change via television, newspapers, books, videos and other promotional tools and instruments to let the cadres and masses to know and recognize the importance and urgency of dealing with climate change and understand the significant impact of climate change on the development and competitiveness of state, region and enterprises. They must promote the participation of the whole nation, encourage local businesses to take actions, advocate a healthy and civilized concept of consumption, increase corporate social responsibility, and initiatively develop and implement the goals and measures of carbon emissions reduction.

\subsection{Our Countries Should Strengthen International Low-Carbon Technology Transfer and Finance Cooperation}

The specific stage of China's economic development determines that if it cannot upgrade the technology effectively and make use of the low-carbon technologies as soon as possible, it will result in the lock-in effect of a large part of the infrastructure and industrial equipment and lead directly to the significant increase of $\mathrm{CO}_{2}$ emissions. This will impact China as well as the global climate. Therefore, we should learn from South Korea's international cooperation and environmental diplomatic strategy and establish the strategic diplomacies with neighboring countries through energy and technical cooperation. At present, China has the problem of insufficient incentives in the international transfer and cooperation of low-carbon technology. It is impossible to complete such a task against its own economic effectiveness relying 
solely on enterprises' spontaneous behaviors. Therefore, from all stakeholders point of view, the country should give full play to the government's guiding role in lowcarbon technology transfer and cooperation and provide positive incentives to overcome various obstacles for the private sectors' participation in international technical cooperation through the joint efforts of the developed and developing countries.

\subsection{The Chinese Government Should Learn from Korean Government, Who Is Well Aware that both Science and Technology R\&D and the Industrial Upgrading Are Inseparable from Education Support}

To this end, the Korean government has been trying to increase investment in environmental knowledge education and improve the education system. The main approach is to introduce the contents of environmental protection and ecological ethics related to green growth to the teaching materials of the primary and middle schools and to promote courses of environment and green growth in the middle and high schools. In addition, it also actively guides students to visit the Nature Museum and Science Museum for green growth experiences, thus increasing students' recognition of the environment and sustainable economic developing concept from the level of the whole society. It also provides a great inspiration to our country. We should commit to achieving the transformation of low-carbon economy in a broad sense, recognize the important role of national education in enhancing the citizens' environmental awareness and concept of green consumption, thus improving green economy development and environmental diplomacy from the bottom to the top.

\section{REFERENCES}

[1] Y. Lee, "The Social and Economic Policies for the Sustainable Economic Growth in South Korea," Korean Trade Association, 2002. [Korean]

[2] South Korean Ministry of Knowledge Economy, "South Korea Introduces Five-Year Plan for the Local Economic Development in Order to Promote the Sustainability of Economic Equilibrium,” Working Report, 2009, unpublished. [Korean] http://kr.mofcom.gov.cn/aarticle/jmxw/200909/20090906 527287.html
[3] Korean Model of Green Growth Strategy, "Speech in Zhongguancun Forum in 2009 by Piao Yinzhe,” Head of the Economic Free Zone Department in Kyongbuk of Taegu, South Korea, unpublished. [Korean]

[4] Committee on Green Growth, "The National Strategy and Five-Year Plan for Green Growth,” 2009. [Korean] http://www.greengrowth.go.kr

[5] S. Bo, "South Korea Implements Green Economy and Focuses on Science and Technology, Prospects of Global Sci-Tech Economy," Global Economy Outlook, Vol. 26, No. 5, 2011, pp. 17-20. [Chinese]

[6] F. Bai, "Diplomacy with Economic Recovery as the Center-Exploration of the Possible Low-Carbon and Green Growth Model in the Developing Countries,” The Special Issues Themed as How to Recover the National Economy, South Korean Minister of Foreign Affairs and Trade, 2009. [Korean]

[7] Education Section of Chinese Embassy in South Korea, "The Report Material of Korean Ministry of Education, Science and Technology: Lee Myung-bak Government's Results of Green Growth Policies in Promoting the Green Growth Policy, Education, Science and Technology Policies Change-Expanding the Investment in Green Technology and Cultivating Personnel in Green Growth,” World Education Information, Vol. 8, No. 1, 2008. [Korean]

[8] The Ministry of Planning and Finance in South Korean, "2010 South Korea's National Competitiveness Report," 2010, unpublished. [Korean]

http://www.mofcom.gov.cn/aarticle/i/jyjl/j/201209/20120 908324504.html

[9] Samsung Economic Research Institute, "New Key Words for SMEs-Green,” SERI Economic Focus, Vol. 2, No. 342, 2011, pp. 1-22. [Korean]

[10] W. Wu and Z. Lee, “Cases for Korean Enterprises’ LowCarbon Green Strategy,” Enterprise Management, Vol. 5, No. 1, 2010, pp. 51-54. [Chinese]

[11] The Sustainable Development Committee in South Korea, "Presidential Commission on Sustainable Development," 2010-2011 Government Report Data, unpublished. [Korean]

[12] Y. Piao, "South Korean Model of Green Growth Strategy,” Zhongguancun Forum in 2009, unpublished. [Korean]

[13] C. Lie, "South Korea Increases R\&D Efforts and Develops the Green Economy," Construction Machinery and Equipment, Vol. 2, No. 1, 2010, p. 75. [Chinese]

[14] L. Jin, L. Wang and L. Yin, "Information Technology: New Power for Green Growth in South Korea,” Shanghai Informatization, Vol. 11, No. 1, 2009, pp. 82-85. [Chinese] 